\title{
IMPLEMENTASI BLENDED LEARNING PADA PEMBELAJARAN SKI MI SEBAGAI PENGUATAN LITERASI DIGITAL MENDESAIN E-LEARNING BERBASIS BLOGGER DAN GOOGLE FORM
}

\author{
Muhammad Nasir ${ }^{1}$, Syarifuddin ${ }^{2}$, Ahmad Rifa'i ${ }^{3}$ \\ ${ }^{123}$ Dosen STIQ Amuntai, Kalimantan Selatan, Indonesia \\ 1nasirmuning@gmail.com, ${ }^{2}$ syarifuddin.stiq@gmail.com, \\ 3ahmadrifai210788@gmail.com
}

\begin{abstract}
Abstrak
Pembelajaran online merupakan solusi alternatif yang harus dikembangkan oleh para pendidik seperti pembelajaran online berbasis blogger dan evaluasi online berbasis google form, disaat pengembangan elearning yang mahal dan perlu SDM terampil dalam mengembangkan teknologi pendidikan. Oleh karena itu calon pendidik khususnya mahasiswa keguruan harus dibekali kompetensi ini sebagai penguatan literasi digital. Metode penelitian menggunakan metode kombinasi model sequential exploratory design, pada tahap awal menggunakan metode kualitatif deskriptif kemudian selanjutnya menggunakan metode kuantitatif deskriptif. Hasil penelitian implementasi blended learning diterapkan dengan menggunakan Alternative Model Blended Learning terdiri lima tahapan yaitu 1) membuat rumusan capaian pembelajaran, 2) mendeskripsikan dan menyusun materi pembelajaran, dan 3) menetapkan dan menentukan aktivitas pembelajaran. Kemampuan literasi digital mahasiswa dalam mendesain pembelajaran berbasis blogger menunjukkan 60\% mahasiswa mampu mendesain e-learning berbasis blogger dengan sangat baik, sedangkan kemampuan literasi digital mahasiswa dalam mendesain evaluasi berbasis google form menunjukkan 70\% mahasiswa mampu mendesain evaluasi online berbasis google form dengan sangat baik.
\end{abstract}

Keywords: E-Learning, Blended Learning, Literasi Digital, Blogger, Google Form

\begin{abstract}
Online learning is an alternative solution that must be developed by educators such as online learning based on bloggers and online evaluation based on google forms, while developing e-learning is expensive and requires skilled human resources in developing educational technology. Therefore, prospective educators, especially teacher students, must be equipped with this competency as a strengthening of digital literacy. The research method uses a combination method of sequential exploratory design models, at the initial stage using descriptive qualitative methods and then using descriptive quantitative methods. The results of the research on the implementation of blended learning were applied using the Alternative Model Blended Learning consisting of five stages, namely 1) formulating learning outcomes, 2) describing and compiling learning materials, and 3) setting and determining learning activities. Students' digital literacy ability in designing blogger-based learning shows $60 \%$ of students are able to design blogger-based elearning very well, while students' digital literacy skills in designing google form-based evaluations show that $70 \%$ of students are able to design google form-based online evaluations very well.
\end{abstract}

Keywords: E-Learning, Blended Learning, Literasi Digital, Blogger, Google Form

Al-Madrasah: Jurnal Ilmiah Pendidikan Madrasah Ibtidaiyah

Vol. 6, No. 1, Januari-Maret 2022 
Muhammad Nasir, Syarifuddin, Ahmad Rifa'I : Implementasi Blended Learning Pada Pembelajaran SKI MI Sebagai Penguatan Literasi Digital Mendesain E-Learning Berbasis Blogger dan Google Form

\section{PENDAHULUAN}

Dunia saat ini dihadapkan dengan sebuah permasalahan yang sangat luar biasa bersifat global yaitu adalah covid-19 (Coronavirus Disease 2019), virus ini menyebar dengan cepat hampir ke seluruh dunia termasuk Indonesia. Dampak negatif dari virus ini dapat dirasakan di semua sektor kehidupan dari segi perekonomian, pemerintahan, perdagangan termasuk juga dunia pendidikan. ${ }^{1}$

Covid-19 memaksa menteri pendidikan untuk membuat kebijakan tidak melaksanakan proses pendidikan seperti biasa yaitu tatap muka atau hadir ke sekolah dan belajar di kelas, menteri pendidikan mewajibkan proses pembelajaran dilakukan secara online. ${ }^{2}$

Kebijakan tersebut mengharuskan pegiat pendidikan membuat sebuah terobosan yang inovatif untuk bisa melangsungkan pembelajaran yang efektif, cara yang dilakukan oleh para guru ataupun dosen dalam melakukan pembelajaran, seperti melaksanakan pembelajaran via grup WhatsApp, streaming Zoom, Google Classroom, ${ }^{3}$ streaming YouTube, ${ }^{4}$ pembelajaran berbasis web/blog, ${ }^{5}$ Learning Management System (LMS) Seperti; Moodle, ${ }^{6}$ Chamilo $^{7}$ dan lain-lain.

Semua kreativitas yang disebutkan di atas mempunyai efektifitas yang berbeda-beda dapat dipengaruhi oleh beberapa hal diantaranya biaya, sumber daya para pendidik (SDM),

1 Zaharah Zaharah, Galia Ildusovna Kirilova, and Anissa Windarti, "Impact of Corona Virus Outbreak Towards Teaching and Learning Activities in Indonesia," Salam: Jurnal Sosial Dan Budaya Syar$i$, no. 3 (2020): 269-82.

2 Firman Firman and Sari Rahayu, "Pembelajaran Online Di Tengah Pandemi Covid-19," Indonesian Journal of Educational Science (IJES) 2, no. 2 (April 27, 2020): 81-89, https://doi.org/10.31605/ijes.v2i2.659.

${ }^{3}$ Ibnu Habibi, "Implementasi Pembelajaran Pendidikan Agama Islam Berbasis Daring (Whatsapp Group, Google Classroom Dan Zoom Meeting) Di SMP MBS Al Amin Bojonegoro," CENDEKIA 12, no. 2 (October 23, 2020): 161-78, https://doi.org/10.37850/cendekia.v12i2.134.

${ }^{4}$ Ahmad Nursobah, "Pemanfaatan Media Sosial Youtube Pada Pembelajaran Sejarah Kebudayaan Islam Di Madrasah Ibtidaiyah," El Midad 13, no. 2 (December 22, 2021): 76-85, https://doi.org/10.20414/elmidad.v13i2.4122.

${ }^{5}$ Erna Nopitasari, Fitri Puji Rahmawati, and Wahyu Ratnawati, "Blended Learning Berbasis Blog Sebagai Inovasi Pembelajaran Pada Masa Pandemi Untuk Meningkatkan Motivasi Belajar Peserta Didik Kelas 3 Sekolah Dasar," Educatif Journal of Education Research 4, no. 1 (2022): 1-7, https://doi.org/10.36653/educatif.v4i1.86.

${ }^{6}$ Matilda Ujulawa, "Perancangan Learning Management System (LMS) Menggunakan Moodle Pada Sekolah Tinggi Tarakanita Jakarta," Komputasi: Jurnal Ilmiah Komputer \& Sistem Informasi 16, no. 1 (2017): 61-69.

7 Dwi Suseno Wati, Sardianto Markos Siahaan, and Ketang Wiyono, "Efektivitas Learning Management System Chamilo Materi Gerak Harmonik Sederhana Terhadap Hasil Belajar Peserta Didik," LENSA (Lentera Sains): Jurnal Pendidikan IPA 11, no. 2 (October 31, 2021): 100-109, https://doi.org/10.24929/lensa.v11i2.166.

Al-Madrasah: Jurnal Ilmiah Pendidikan Madrasah Ibtidaiyah

Vol. 6, No. 1, Januari-Maret 2022 
Muhammad Nasir, Syarifuddin, Ahmad Rifa'I : Implementasi Blended Learning Pada Pembelajaran SKI MI Sebagai Penguatan Literasi Digital Mendesain E-Learning Berbasis Blogger dan Google Form

fasilitas dan waktu. Pembelajaran menggunakan via grup WhatsApp mungkin bisa dilakukan karena hampir seluruh guru pasti mempunyai fasilitas ini begitu juga siswa, akan tetapi pembelajaran kurang efektif karena banyak hal yang terlewatkan seperti penyampaian materi, kontrol kelas, dan lain-lain. Tetapi ini bisa jadi solusi akhir yang paling bisa dilakukan pada saat ini.

Mengembangkan sebuah Learning Management System (LMS) dengan fitur yang lengkap sudah tersistematis sebagai sebuah sistem manajemen pembelajaran di sana sudah ada fitur absensi, fitur presentasi, fitur evaluasi dan lain sebagainya. Tetapi untuk mengembangkan LMS tidak murah dan tidak mudah karena memerlukan server atau hosting untuk instalasi LMS, selain itu juga memerlukan skill yang mumpuni agar bisa mendesain sebuah pembelajaran di LMS.

Fakta di lapangan menurut Windo Wiriadinata and Fahmil Haris menjelaskan bawah 69\% hanya sedikit memahami tentang e-learning sehinga pelaksanaan e-learning belum digunakan secara maksimal, ${ }^{8}$ hal ini menunjukan bahwa tidak semua guru mempunyai kemampuan dan fasilitas untuk melaksanakan pembelajaran online termasuk juga yang berbasis LMS, di samping itu juga tidak semua siswa mempunyai fasilitas (gadget dan internet) untuk bisa mengikuti proses pembelajaran seperti ini. ${ }^{9}$ Jika ingin menerapkan LMS maka memerlukan biaya yang tak murah, fasilitas harus lengkap, memberikan pelatihan agar para pendidik mampu melaksanakan pembelajaran berbasis LMS sehingga memerlukan waktu yang cukup lama sedangkan proses pembelajaran tetap harus dilaksanakan. ${ }^{10}$

Menggunakan pembelajaran streaming seperti Zoom yang memungkinkan kita untuk bisa bertatap muka secara virtual, akan tetapi ini memerlukan data atau paket internet yang cukup banyak untuk bisa masuk ke streaming Zoom, di samping itu kita harus memberi lisensi dari Zoom untuk mendapatkan fitur premium yang akan kita gunakan pada proses pembelajaran.

Pembelajaran berbasis website atau blog bisa menjadi salah satu solusi agar para pendidik bisa melaksanakan proses pembelajaran dengan murah dan tidak memerlukan skill yang tinggi

\footnotetext{
${ }^{8}$ Windo Wiriadinata and Fahmil Haris, "Tingkat Pemahaman Guru Penjas Terhadap Penerapan ELearning Dalam Proses Pembelajaran Di Sekolah Menengah Pertama Kabupaten Limapuluh Kota Bukik Barisan," Jurnal Stamina 2, no. 12 (2019): 12-19.

9 "Kesulitan Akses Internet, Siswa Di Nagekeo Berjuang Cari Sinyal Hingga Ke Perbukitan Regional Liputan6.Com,” accessed January 22, 2022, https://www.liputan6.com/regional/read/4503480/kesulitan-akses-internet-siswa-di-nagekeo-berjuang-carisinyal-hingga-ke-perbukitan.

10 "Kenali 4 Kekurangan Sistem Pendidikan Online Berbasis Open-Source," Kenali 4 Kekurangan Sistem Pendidikan Online Berbasis Open-Source, accessed January 22, 2022, https://www.akubelajar.id/blog/kenali-4-kekurangan-sistem-pendidikan-online-berbasis-open-source.
}

Al-Madrasah: Jurnal Ilmiah Pendidikan Madrasah Ibtidaiyah

Vol. 6, No. 1, Januari-Maret 2022 
Muhammad Nasir, Syarifuddin, Ahmad Rifa'I : Implementasi Blended Learning Pada Pembelajaran SKI MI Sebagai Penguatan Literasi Digital Mendesain E-Learning Berbasis Blogger dan Google Form

cukup dengan fasilitas smartphone atau laptop, dan mempelajari skill ini tidak memerlukan waktu yang lama. Pembelajaran berbasis website bisa kita integrasikan kan dengan fitur-fitur lain seperti streaming YouTube, menampilkan materi, melaksanakan evaluasi, serta absen kehadiran.

Dari beberapa solusi di atas dapat kita simpulkan bahwa setiap pembelajaran berbasis online mempunyai kekurangan dan kelebihan masing-masing dan efektivitas dapat dipengaruhi oleh faktor-faktor yang berbeda di setiap lembaga pendidikan, sehingga pembelajaran berbasis website atau blog sangat memungkinkan untuk kita laksanakan berdasarkan alasan-alasan yang sudah dijelaskan di atas.

\section{METODE PENELITIAN}

Penelitian ini menggunakan metode kombinasi model sequential exploratory design, pada tahap awal menggunakan metode kualitatif deskriptif kemudian selanjutnya menggunakan metode kuantitatif deskriptif. ${ }^{11}$ Kualitatif deskriptif digunakan untuk mendeskripsikan implementasi blended learning pada mata kuliah SKI MI sebagai penguatan literasi digital mahasiswa dan Kuantitatif deskriptif digunakan untuk mendeskripsikan kompetensi literasi digital mahasiswa jurusan PGMI di Sekolah Tinggi Ilmu Al-Qur'an (STIQ) Amuntai.

Adapun yang dimaksud literasi digital dalam penelitian ini adalah kemampuan mendesain pembelajaran online dengan blogger dan kemampuan membuat evaluasi online dengan google form. Populasi dalam penelitian ini adalah seluruh mahasiswa jurusan PGMI semester 5 tahun ajaran 2021/2022 yang mengikuti mata kuliah Pembelajaran SKI MI di Sekolah Tinggi Ilmu AlQur'an (STIQ) Amuntai, adapun sampel dalam penelitian ini menggunakan teknik random sampling (Probability sampling) dengan metode Simple Random Sampling. Sampel dari lokal A berjumlah 7 mahasiswi, lokal B berjumlah 9 mahasiswi dan lokal $\mathrm{C}$ berjumlah 4 mahasiswa. Kemudian membagikan materi SKI MI untuk dijakan sebagai isi materi desain pembelajaran online yang akan dikembangkan, mahasiswa membuat group teacher yang terdiri dari satu orang atau lebih.

Teknik pengumpulan data dengan dokumetasi dan tes kompetensi literasi digital pada kemampuan mendesain pembelajaran online berbasis blogger dan evaluasi online di google form. Analisis data yang digunakan adalah analisis kuanlitatif deskriptif dan kuantitatif deskriptif yang h. 276 .

\footnotetext{
${ }^{11}$ Sugiyono, Cara mudah menyusun skripsi, tesis, dan disertasi (STD) (Bandung: Alfabeta, 2013),
}

Al-Madrasah: Jurnal Ilmiah Pendidikan Madrasah Ibtidaiyah

Vol. 6, No. 1, Januari-Maret 2022 
Muhammad Nasir, Syarifuddin, Ahmad Rifa'I : Implementasi Blended Learning Pada Pembelajaran SKI MI Sebagai Penguatan Literasi Digital Mendesain E-Learning Berbasis Blogger dan Google Form

diambil dari nilai tes kompetensi literasi digital. Berikut ini tabel indikator kemampuan literasi digital yang digunakan untuk mengalisis hasil penelitian.

Tabel Indikator Tingkat Kemampuan Literasi Digital Desain E-learning berbasis Blogger dan Evaluasi Google Form

\begin{tabular}{|l|l|c|}
\hline Kategori & \multicolumn{1}{|c|}{ Kisi-kisi } & $\begin{array}{l}\text { Rata- } \\
\text { rata }\end{array}$ \\
\hline Basic & $\begin{array}{l}\text { Kemampuan dalam mengoperasikan dan mengakses media } \\
\text { pembelajaran tidak terlalu tinggi, kemampuan dalam } \\
\text { menganalisa konten media tidak terlalu baik, dan } \\
\text { kemampuan berkomunikasi serta menyampaikan pendapat } \\
\text { melalui media terbatas. }\end{array}$ & \\
\hline Medium & $\begin{array}{l}\text { Kemampuan dalam mengoperasikan dan mengakses media } \\
\text { pembelajaran cukup tinggi, kemampuan dalam } \\
\text { menganalisa dan mengevaluasi konten media cukup baik, } \\
\text { dan aktif dalam memproduksi konten media dan } \\
\text { berpartisipasi secara sosial }\end{array}$ & \\
\hline Advanced & $\begin{array}{l}\text { Kemampuan dalam mengoperasikan dan mengakses media } \\
\text { pembelajaran sangat tinggi, memiliki pengetahuan yang } \\
\text { tinggi sehingga mampu menganalisa konten media secara } \\
\text { mendalam, dan mampu berkomunikasi secara aktif melalui } \\
\text { media }\end{array}$ & \\
\hline
\end{tabular}

Sumber: Liya Atika Anggrasari ${ }^{12}$

\section{HASIL DAN PEMBAHASAN}

\subsection{Implementasi Blended Learning}

Setelah menentukan sampel kemudian mengimplementasikan blended learning jenis Alternative Model Blended Learning yang dikembangkan oleh Yaumi \& Damopolii ${ }^{13}$, berikut tabel desain model pembelajaran Alternative Model Blended Learning.

Tabel Alternative Model Blended Learning

\begin{tabular}{|l|l|l|l|l|l|l|l|l|l|l|l|l|l|l|l|}
\hline \multicolumn{10}{|c|}{ Pertemuan ke- } \\
\hline 1 & 2 & 3 & 4 & 5 & 6 & 7 & 8 & 9 & 10 & 11 & 12 & 13 & 14 & 15 & 16 \\
\hline \multicolumn{11}{|c|}{ Pembelajaran Offline } \\
(Diskusi, Presentasi, dan Umpan balik) \\
Pembelajaran Online \\
\hline \multicolumn{11}{|c|}{ (Bahan ajar, tugas, latihan, video praktikum, peer review) }
\end{tabular}

Sumber: Rahmawati Putri 2021

Model pembelajaran alternative blended learning digunakan pada penelitian ini dengan alasan bahwa model ini memberikan alokasi waktu yang sama antara pembelajaran online dan

12 Liya Atika Anggrasari, "Penerapan E-Learning Untuk Meningkatkan Kemampuan Literasi Digital Di Era New Normal," Premiere Educandum : Jurnal Pendidikan Dasar Dan Pembelajaran 10, no. 2 (December 1, 2020): h. 251., https://doi.org/10.25273/pe.v10i2.7493.

${ }^{13}$ Rahmawida Putri, Model Blended Learning Berbasis Quided Inquiry (Sukoharjo: Penerbit Tahta Media Group, 2021), h. 41.

Al-Madrasah: Jurnal Ilmiah Pendidikan Madrasah Ibtidaiyah

Vol. 6, No. 1, Januari-Maret 2022 
Muhammad Nasir, Syarifuddin, Ahmad Rifa'I : Implementasi Blended Learning Pada Pembelajaran SKI MI Sebagai Penguatan Literasi Digital Mendesain E-Learning Berbasis Blogger dan Google Form

offline, ${ }^{14}$ hal ini sesuai dengan kebijakan yang diterapkan di Sekolah Tinggi Ilmu Al-Qur'an (STIQ) Amuntai yang masih belum bisa melaksanakan pembelajaran tatap muka secara penuh.

Pada model pembelajaran ini, pembelajaran online hanya sebagai alternative dalam pemberian materi ajar, tugas dalam bentuk individu maupun kelompok, latihan, video pembelajaran. Sedangkan untuk memaksimalkan pembelajaran dilaksanakan pembelajaran secara offline untuk berdiskusi, memaparkan presentasi dan juga menyampaikan umpan balik dari materi pembelajaran yang disampaikan. ${ }^{15}$

Tahapan-tahapan dalam blended learning pada mata kuliah SKI MI adalah sebagai berikut: ${ }^{16}$

a. Membuat Rumusan Capaian Pembelajaran.

Rumusan yang diperoleh adalah mahasiswa mampu mendesain pembelajaran online berbasis blogger pada mata pelajaran SKI MI, dan mahasiswa mampu mendesain evaluasi online dengan memanfaatkan google form.

b. Mendeskripsikan dan Menyusun Materi Pembelajaran.

Pada tahap ini materi dibagi menjadi dua bagian, 1) materi tentang desain pembelajarn berbasis blogger dan 2) evaluasi online dari google form.

c. Menetapkan dan Menentukan Aktivitas Pembelajaran.

Aktifitas pembelajaran dilaksanakan 3 kali pertemuan 2 pertemuan online dan 1 pertemuan offline. Pada pembelajaran online yang digunakan adalah pembelajaran asinkron dengan membuat video pembelajaran terkait dengan materi yang sudah ditentukan. Video pembelajaran diupload ke platform youtube untuk mempermudah mahasiswa mengaksesnya. Berikut link video pembelajaran yang digunakan pada tahap ini.

1) Desain pembelajaran berbasis blogger https://youtu.be/gsdMJtPLBjs

2) Evaluasi online berbasis google form https://youtu.be/UonXuCY_2Ac

Mahasiswa juga bisa bertanya via online dengan dosen jika ada yang tidak dipahami dari video pembelajaran yang disediakan Sedangkan pada pembelajaran offline merupakan simulasi dan laporan desain pembelajaran berbasis blogger dan google form. Jika ada mahasiswa yang masih belum memenuhi kompetensi yang diinginkan maka ada perbaikan yang harus perbaiki oleh mahasiswa.

\footnotetext{
${ }^{14}$ Putri, h. 41.

15 Putri, h. 41-42.

${ }^{16}$ Putri, h. 41-42.
}

Al-Madrasah: Jurnal Ilmiah Pendidikan Madrasah Ibtidaiyah

Vol. 6, No. 1, Januari-Maret 2022 
Muhammad Nasir, Syarifuddin, Ahmad Rifa'I : Implementasi Blended Learning Pada Pembelajaran SKI MI Sebagai Penguatan Literasi Digital Mendesain E-Learning Berbasis Blogger dan Google Form

\subsection{Desain E-Learning Berbasis Blogger}

Sutopo mengutip argumentasi Dabbagh \& Bannan-Ritland tentang pembelajaran online, minimal ada tiga komponen pembelajaran yang terlibat berinteraksi dalam pembelajaran online (e-learning) yaitu; 1) Strategi Pembelajaran, 2) model Pendidikan, 3) teknologi pembelajaran. 1) Strategi Pembelajaran seperti; Project Based Learning, Daring Method, Luring Method, Blended Learning dan lainnya, 2) Model Pendidikan seperti; pendidikan terbuka, fleksibel, terdistribusi, dan Pendidikan Jarak Jauh (PJJ) lain-lain., 3) Teknologi pembelajaran seperti; perangkat komunikasi, perangkat multimedia, course management system, website, learning management system dan lain -lain. ${ }^{17}$

Argumentasi di atas adalah batas komponen minimum, sehingga jika kita ingin menjadikan pembelajaran online yang sama persis dengan pembelajaran offline maka perlu menambah komponen penting lainnya dalam pembelajaran, seperti tujuan Pembelajaran, materi pembelajaran, media pembelajaran, evaluasi pembelajaran, dan hal-hal yang bersifat administratif seperti absensi kehadiran siswa ketika pembelajaran online berlangsung, sehingga terbentuk manajemen sistem pembelajaran yang serupa dengan sistem pembelajaran offline.

Berikut ini model atau desain pembelajaran yang akan didesain dengan mempertimbangkan komponen-komponen penting dalam pembelajaran, perhatikan grafik di bawah ini:

Tabel Mendesain Pembelajaran Online Berbasis Blogger dan Evaluasi Berbasis Google Form

\begin{tabular}{|l|l|}
\hline Model Pendidikan & Model Pendidikan Jarak Jauh (PJJ) \\
\hline Pembelajaran & $\begin{array}{l}\text { - Mata Pelajaran SKI MI Kelas V } \\
\text { - Materi Pembelajaran Teladan Khalifah } \\
\text { Umar bin Khattab } \\
\text { Evaluasi }\end{array}$ \\
\hline Administrasi & Evaluasi Pegi Pembelajaran; Blended Learning \\
\hline Teknologi Pendidikan & Silabus, Perencanaan (RPP), dan Absensi \\
& $\begin{array}{l}\text { - Media Pembelajaran: Website (Blogger), } \\
\text { Video Presentasi, } \\
\end{array}$ \\
\hline
\end{tabular}

3.3. Langkah Langkah Desain E-Learning Berbasis Blogger dan Evaluasi Berbasis Google Form

${ }^{17}$ Ariesto Hadi Sutopo, Teknologi Informasi Dan Komunikasi Dalam Pendidikan (Yogyakarta: Graha Ilmu, 2012), h. 150.

Al-Madrasah: Jurnal Ilmiah Pendidikan Madrasah Ibtidaiyah

Vol. 6, No. 1, Januari-Maret 2022 
Muhammad Nasir, Syarifuddin, Ahmad Rifa'I : Implementasi Blended Learning Pada Pembelajaran SKI MI Sebagai Penguatan Literasi Digital Mendesain E-Learning Berbasis Blogger dan Google Form

Sebelum mendesain pembelajaran online berbasis blogger, siapkan terlebih dahulu konten yang akan dimasukkan ke blogger, dalam desain ini ada empat komponen pembelajaran yang akan dimasukkan ke dalam page dan post yaitu 1) Deskripsi dan tujuan pembelajaran 2) materi pembelajaran 3) evaluasi dan 4) absensi.

Berikut ini desain pembelajaran online yang akan didesain menggunakan platform blogger.

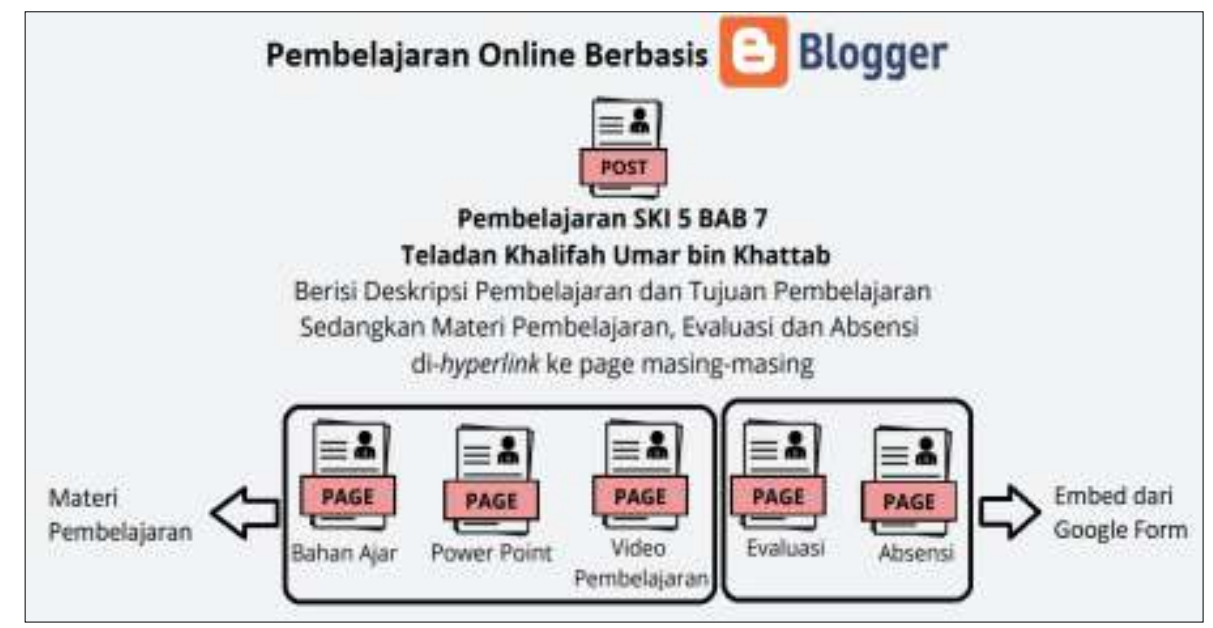

a. Membuat Deskripsi dan Tujuan Pembelajaran

Deskripsi dan tujuan pembelajaran bisa kita isi sesuai dengan silabus atau yang ada pada buku pelajaran, seperti kompetensi inti, kompetensi dasar dan indikator pencapaian kompetensi.

Kemudian buatlah satu postingan dengan judul yang disesuaikan dengan materi pembelajaran yang akan digunakan untuk pembelajaran online. Misalnya judul halamannya adalah "Pembelajaran SKI Kelas 5 Bab 7 Teladan Khalifah Umar bin Khattab". Pastikan pada bagian option komentar di nonaktifkan supaya tidak ada siswa yang menulis komentar di halaman tersebut.

Al-Madrasah: Jurnal Ilmiah Pendidikan Madrasah Ibtidaiyah

Vol. 6, No. 1, Januari-Maret 2022 
Muhammad Nasir, Syarifuddin, Ahmad Rifa'I : Implementasi Blended Learning Pada Pembelajaran SKI MI Sebagai Penguatan Literasi Digital Mendesain E-Learning Berbasis Blogger dan Google Form

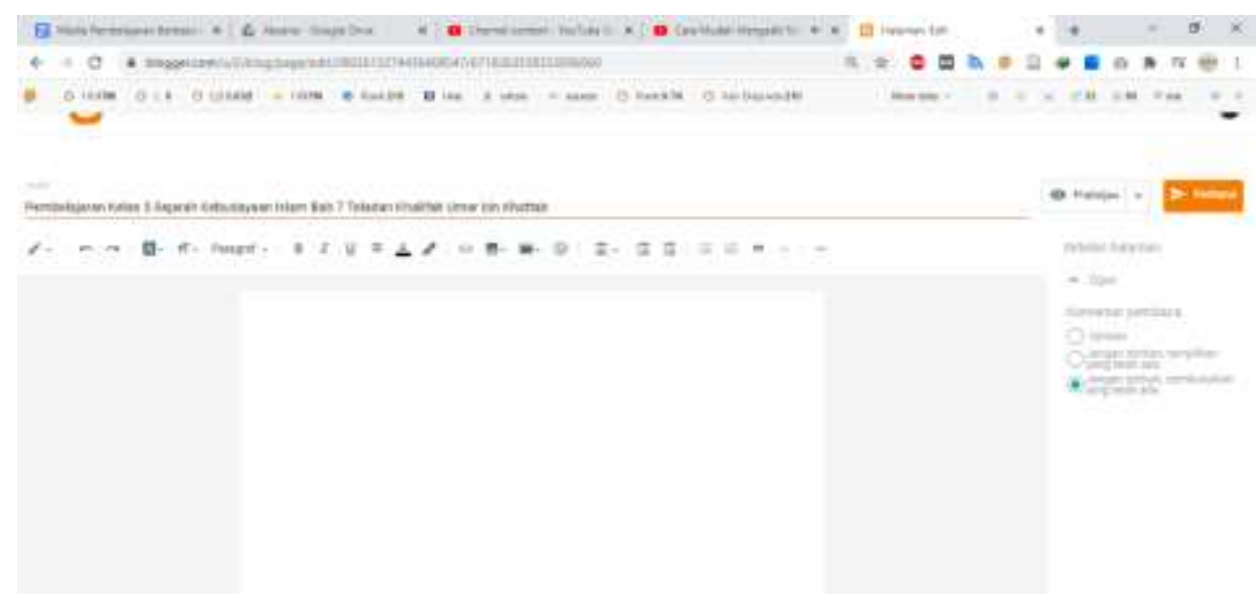

Kemudian isi halaman tersebut dengan deskripi dan tujuan pembelajaran, materi, evaluasi dan absensi, seperti pada gambar dibawah ini atau kunjungi link berikut ini https://blogelearning21.blogspot.com/p/pembelajaran-kelas-5-sejarah-kebudayaan.html.

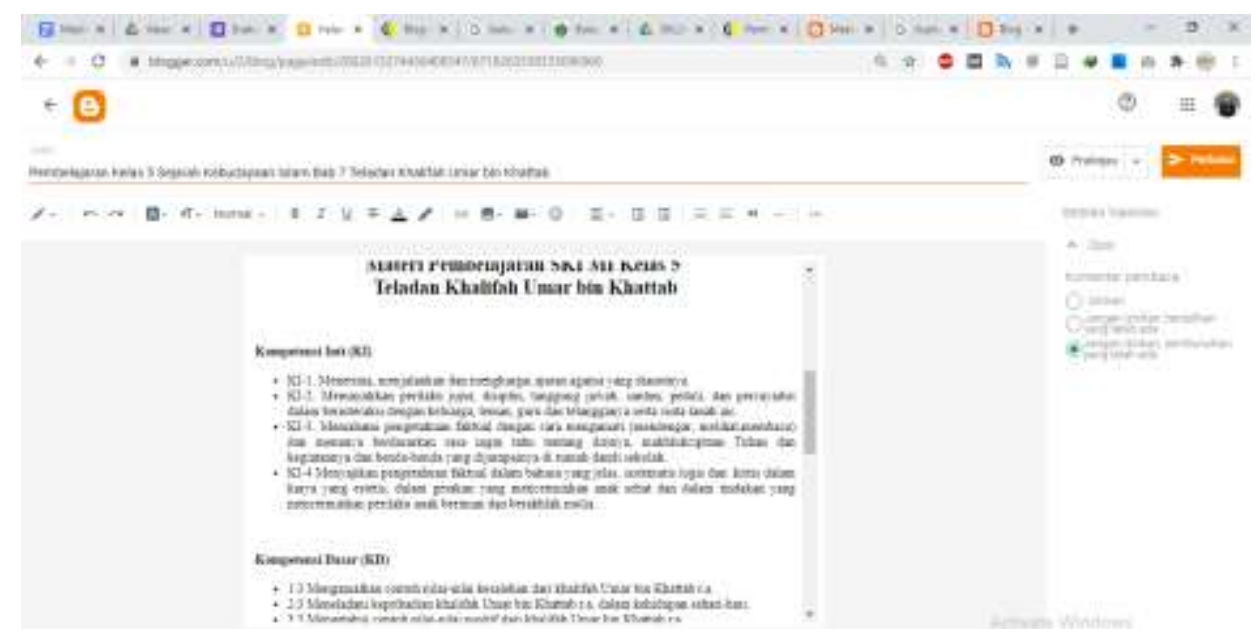

b. Materi Pembelajaran

Materi pembelajaran berisi bahan ajar atau buku pelajaran, video pembelajaran dan file power point yang akan dipublish di page atau halaman blogger.

1) Cara memposting buku pelajaran (pdf)

Buat halaman dengan judul buku pelajaran (sesuaikan dengan materi), isi dengan file buku pelajaran, bisa dengan menggunakan google drive. ${ }^{18}$ Caranya masukkan file buku format pdf

18 Agustinus Rio Trilaksono, T. Husain, and Rouly Doharma, "Uji Model Keberhasilan Sistem Informasi: Media Penyimpanan Google Drive," Jurnal Teknologi Sistem Informasi dan Aplikasi 3, no. 2 (April 30, 2020): h. 58. Google Drive adalah salah satu aplikasi layanan berbasis internet (website) yang

Al-Madrasah: Jurnal Ilmiah Pendidikan Madrasah Ibtidaiyah

Vol. 6, No. 1, Januari-Maret 2022 
Muhammad Nasir, Syarifuddin, Ahmad Rifa'I : Implementasi Blended Learning Pada Pembelajaran SKI MI Sebagai Penguatan Literasi Digital Mendesain E-Learning Berbasis Blogger dan Google Form

ke google drive kemudian tampilkan dan sematkan, copy kode HTML nya dan paste ke postingan buku pelajaran, kemudian publish.

2) Cara memposting video pembelajaran

Video dengan ukuran yang besar tidak bisa diupload ke blogger sehingga kita perlu memanfaatkan youtube atau platform video lainnya untuk memasukkan video pembelajaran. Pertama buatlah postingan dengan judul video pembelajaran (isi sesuai dengan materi). Kemudian untuk mengisi video pembelajaran diupload ke youtube dan buka kode embed (sematkan) dan masukkan ke postingan tadi, kemudian publish.

3) Cara memposting file power point (ppt)

Buat postingan dengan judul power poin pelajaran (disesuaikan dengan materi), isi dengan file power poin, bisa dengan menggunakan google drive. Caranya masukkan file buku format pdf ke google drive kemudian tampilkan dan sematkan, copy kode HTML nya dan paste ke postingan buku pelajaran, kemudian publish.

c. Evaluasi Pembelajaran

Cara memposting evaluasi dengan memanfaatkan fitur google form. Buatlah page di blogger dengan judul evaluasi materi (isi sesuai dengan materi). Kemudian untuk mengisi postingan dengan evaluasi dengan form yang disediakan google form, kunjungi google form di https://docs.google.com/forms/. Kemudian buat form dan isi pertanyaan-pertanyaan yang ingin dijadikan soal evaluasi.

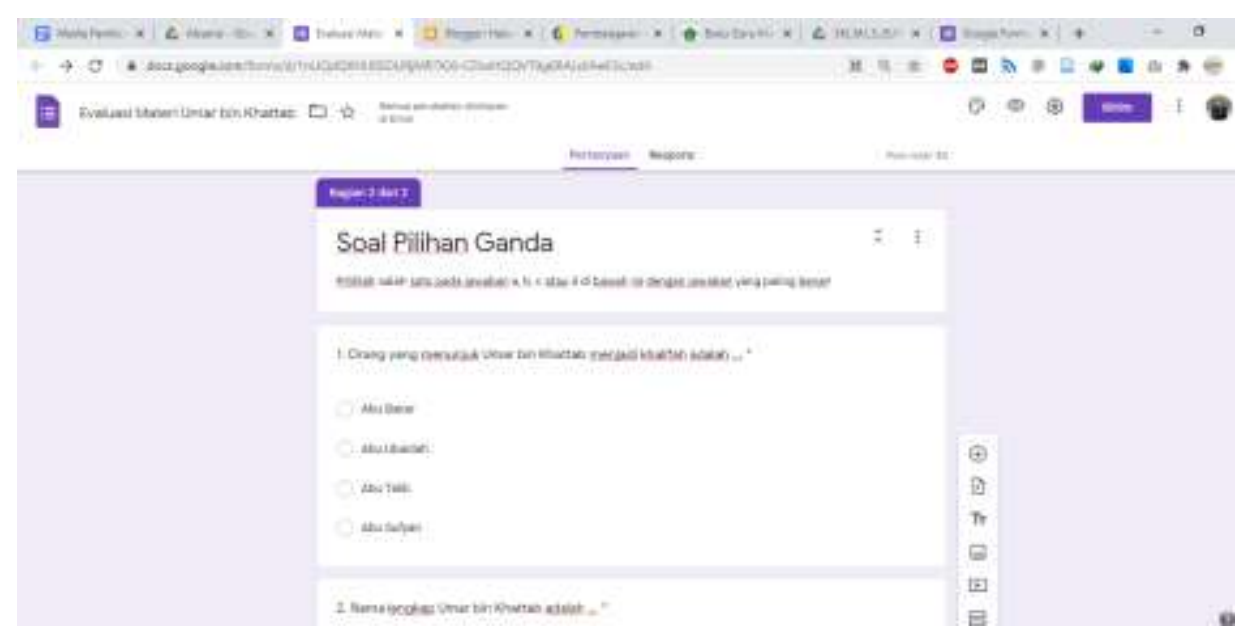

Setelah selesai membuat soal, kemudian klik "setting" untuk mengatur form menjadi format kuis.

memungkinkan pengguna menjadikan media penyimpanan sebagai sumber daya yang dikembangkan oleh perusahaan Google, setiap user diberi kapasitas penyimpanan gratis sebanyak $15 \mathrm{~Gb}$.

Al-Madrasah: Jurnal Ilmiah Pendidikan Madrasah Ibtidaiyah

Vol. 6, No. 1, Januari-Maret 2022 
Muhammad Nasir, Syarifuddin, Ahmad Rifa'I : Implementasi Blended Learning Pada Pembelajaran SKI MI Sebagai Penguatan Literasi Digital Mendesain E-Learning Berbasis Blogger dan Google Form

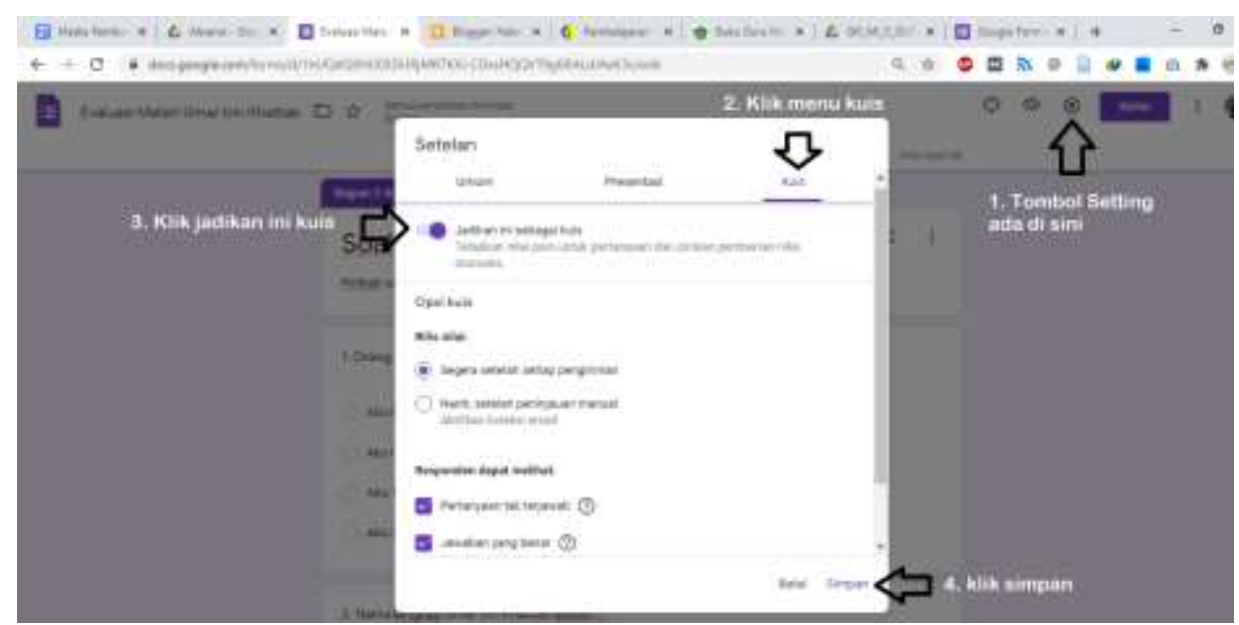

Kemudian beri poin nilai untuk jawaban yang benar di setiap pertanyan, dengan mengklik pertanyaan sampai ada tulisan "jawaban pertanyaan" dan klik tulisan tersebut.

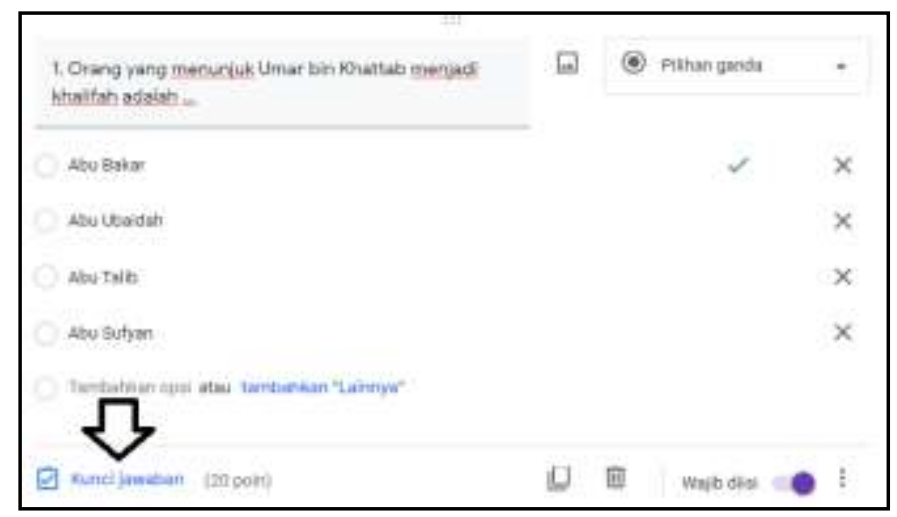

Klik jawaban yang benar, kemudian beri poin skor yang diperoleh jika jawabannya benar, sebagai contoh misalnya ada 5 soal maka poin atau skor setiap soal adalah 20, etelah itu klik simpan.

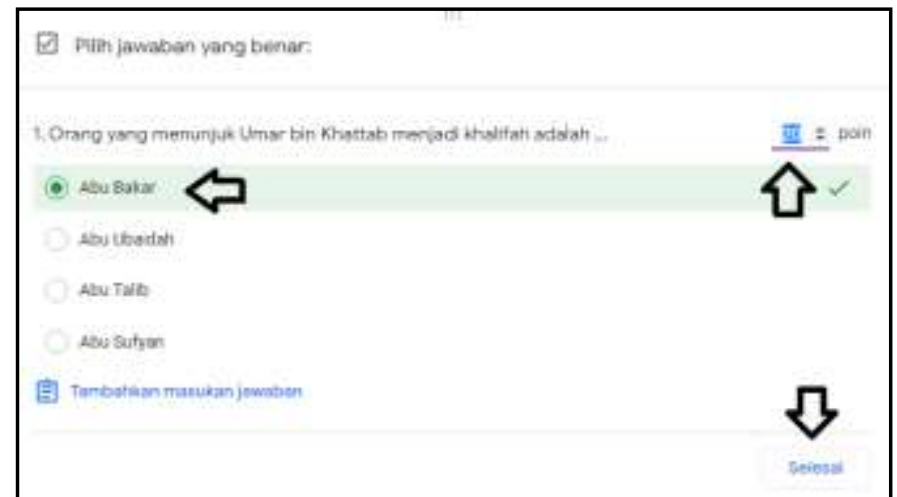

Kemudian embed atau sematkan form soal tadi ke postingan evalauasi yang sudah dibuat tadi, dengan cara klik tombol kirim, cari menu sematkan dan copy code HTML yang sudah tersedia disana.

Al-Madrasah: Jurnal Ilmiah Pendidikan Madrasah Ibtidaiyah

Vol. 6, No. 1, Januari-Maret 2022 
Muhammad Nasir, Syarifuddin, Ahmad Rifa'I : Implementasi Blended Learning Pada Pembelajaran SKI MI Sebagai Penguatan Literasi Digital Mendesain E-Learning Berbasis Blogger dan Google Form

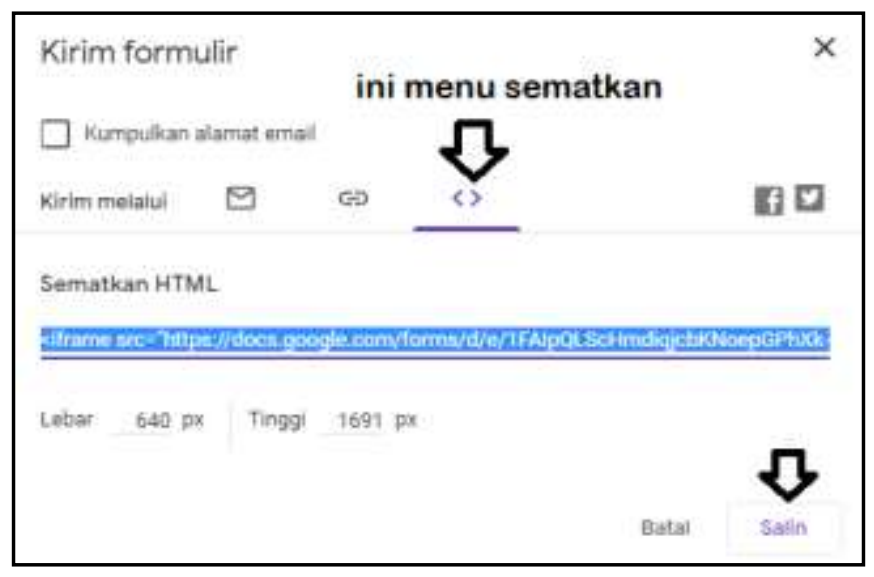

Setelah mengopy code HTML tersebut masuk ke laman isian postingan, klik icon edit disebelah kiri atas untuk memilih tampilan HTML.

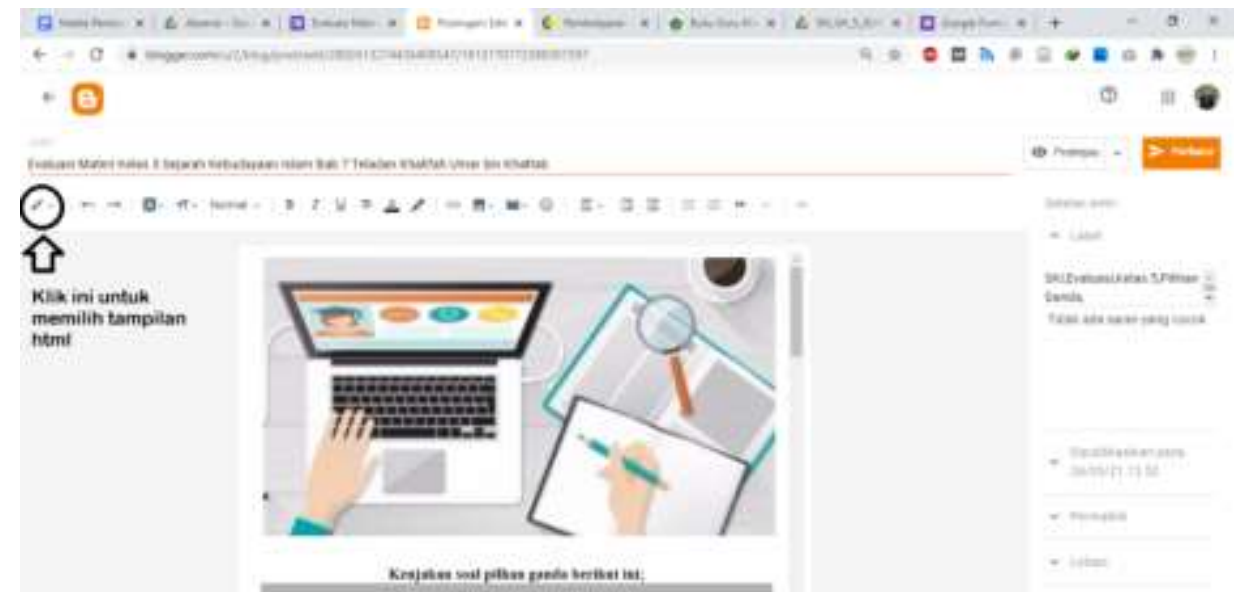

Paste atau tempel code HTML dari google form tadi ke isian tampilan HTML, kemudian publish.

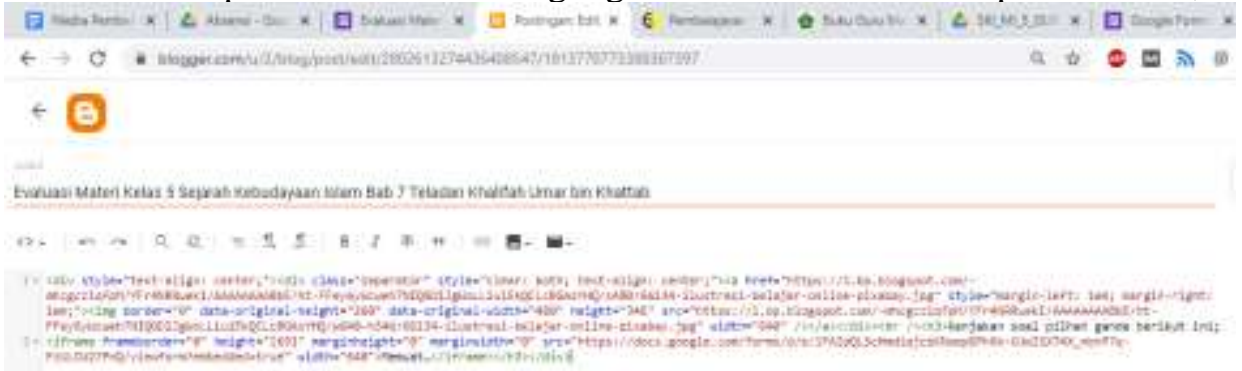

Al-Madrasah: Jurnal Ilmiah Pendidikan Madrasah Ibtidaiyah

Vol. 6, No. 1, Januari-Maret 2022 
Muhammad Nasir, Syarifuddin, Ahmad Rifa'I : Implementasi Blended Learning Pada Pembelajaran SKI MI Sebagai Penguatan Literasi Digital Mendesain E-Learning Berbasis Blogger dan Google Form

\section{d. Absensi dan Monitoring Absensi}

Absensi hampir sama dengan cara google form di atas, buat form nya kemudian sematkan ke halaman atau postingan absensi, begitu juga monitoring absensi, hanya saja untuk monitoring formatnya google sheet. ${ }^{19}$

e. Finishing

Kemudian langkah terakhir adalah membuat hyperlink ${ }^{20}$ di postingan pembelajaran online yang telah dibuat dan berisikan judul materi, tujuan pembelajaran, materi, evaluasi dan absensi. Siapkan url page yang telah kita buat sebelumnya yaitu;

1) url buku pelajaran

Url page-nya adalah https://blogelearning21.blogspot.com/p/buku-siswa-sejarah-kebudayaanislam.html

2) url ppt pembelajaran

Url page-nya adalah https://blogelearning21.blogspot.com/p/power-pont-materi-kelas-5sejarah.html

3) url video pembelajaran

Url page-nya adalah https://blogelearning21.blogspot.com/p/video-pembelajaran-kelas-5sejarah.html

4) url evaluasi

Url page-nya adalah https://blogelearning21.blogspot.com/p/evaluasi-materi-kelas-5sejarah.html

5) url absensi

Url page-nya adalah https://blogelearning21.blogspot.com/p/absensi-kelas-5.html

6) url monitoring

Url page-nya adalah https://blogelearning21.blogspot.com/p/monitoring-absensi-kelas-5.html Kemudian masuk ke menu edit postingan, dan buat hyperlink sesuai keperluan, misalnya memasukkan hyperlink bahan ajar, caranya blok kalimat "Buku Siswa SKI MI Kelas 5" kemudian klik edit link.

${ }^{19}$ platform berbasis web dikembangkan oleh google yang memiliki fitur yang hampir sama dengan Microsoft Office Excel Rachman Arief, “Aplikasi Presensi Siswa Online Menggunakan Google Forms, Sheet, Sites, Awesome Table Dan Gmail” 2017 (2017): 8.

${ }^{20}$ Fathurrahman, Membuat Website Mudah dan Praktis dengan Weebly (Jakarta: Elex Media Komputindo, 2014), h. 75. Hyperlink adalah suatu bagian dari halaman website yang menghubungkan antar halaman, menyediakan hubungan antar link.

Al-Madrasah: Jurnal Ilmiah Pendidikan Madrasah Ibtidaiyah

Vol. 6, No. 1, Januari-Maret 2022 
Muhammad Nasir, Syarifuddin, Ahmad Rifa'I : Implementasi Blended Learning Pada Pembelajaran SKI MI Sebagai Penguatan Literasi Digital Mendesain E-Learning Berbasis Blogger dan Google Form

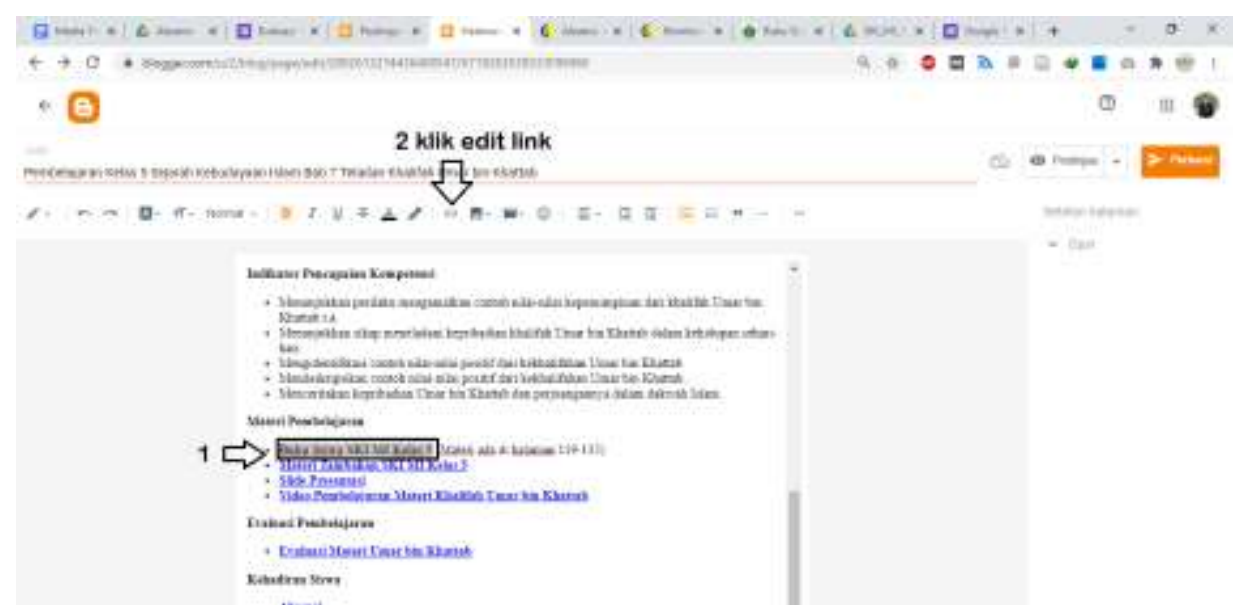

Setelah itu muncul jendela edit seperti ini, masukkan link url buku pelajaran, contreng buka link dengan jendela baru agar setiap kita mengklik hyperlink maka akan membuka jendela browser baru, setelah itu klik terapkan.

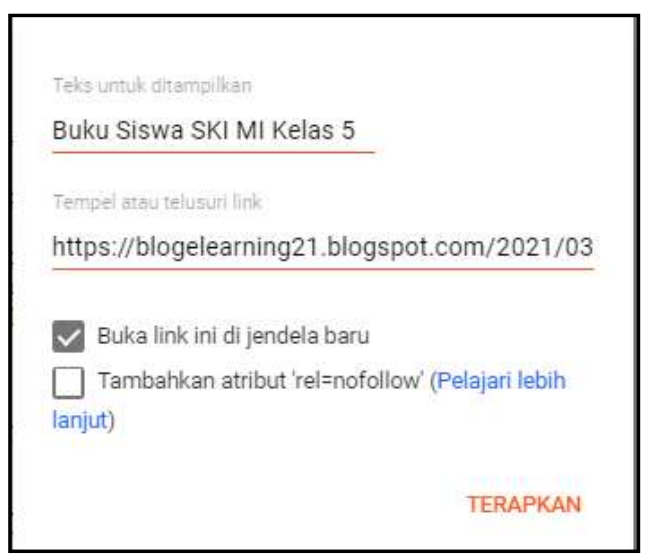

Lakukan langkah tersebut dengan url yang lain untuk membuat hyperlink. Untuk memastikan hyperlink bisa bekerja dengan baik buka tampilan halaman pembelajaran, dan coba klik hyperlink satu persatu, jika ada yang tidak berfungsi maka perlu diperbaiki lagi di menu edit halaman. tetapi jika semuanya sudah berfungsi maka media pembelajaran berbasis blog sudah selesai dibuat.

\subsection{Kemapuan Literasi Digital Mahasiswa}

Tingkat kemampuan literasi digital desain e-learning berbasis blogger dan evaluasi google form dengen menerapkan blended learning pada mata kuliah SKI MI, sebagai berikut;

Tabel Tingkat Kemampuan Literasi Digital Desain E-learning berbasis Blogger dan Evaluasi Google Form

\begin{tabular}{|c|c|c|c|}
\hline Kategori & $\begin{array}{c}\text { Rata-rata } \\
\text { Nilai }\end{array}$ & $\begin{array}{c}\text { E-learning } \\
\text { Berbasis }\end{array}$ & $\begin{array}{c}\text { Evaluasi } \\
\text { Berbasis }\end{array}$ \\
\hline
\end{tabular}

Al-Madrasah: Jurnal Ilmiah Pendidikan Madrasah Ibtidaiyah

Vol. 6, No. 1, Januari-Maret 2022 
Muhammad Nasir, Syarifuddin, Ahmad Rifa'I : Implementasi Blended Learning Pada Pembelajaran SKI MI Sebagai Penguatan Literasi Digital Mendesain E-Learning Berbasis Blogger dan Google Form

\begin{tabular}{|l|c|c|c|c|c|}
\hline \multirow{2}{*}{} & & \multicolumn{2}{|c|}{ Blogger } & \multicolumn{2}{c|}{ Google Form } \\
\cline { 3 - 6 } & & $f$ & $\%$ & $f$ & $\%$ \\
\hline Basic & $55-69$ & 2 & $20 \%$ & 1 & $10 \%$ \\
\hline Medium & $70-84$ & 2 & $20 \%$ & 2 & $20 \%$ \\
\hline Advanced & $85-100$ & 6 & $60 \%$ & 7 & $70 \%$ \\
\hline \multicolumn{2}{|c|}{ Jumlah } & 10 & 100 & 10 & 100 \\
\hline
\end{tabular}

Dari tabel di atas diketahui bahwa kemampuan literasi digital mahasiswa dalam mendesain pembelajaran berbasis blogger mayoritas berada kategori advanced sebanyak 6 group teacher dari total yang diteliti 10 group teacher atau sebanyak 60\%, 2 group teacher berada pada kategori medium atau sebanyak 20\% dan 2 group teacher berada pada kategori basic atau sebanyak 20\%. Hal ini menunjukkan bahwa $60 \%$ mahasiswa mempunyai kemampuan dalam mengoperasikan dan mengakses media pembelajaran sangat tinggi, memiliki pengetahuan yang tinggi sehingga mampu menganalisa konten media secara mendalam, dan mampu berkomunikasi secara aktif melalui media pembelajaran yang sudah disediakan sehingga mampu mendesain elearning berbasis blogger dengan sangat baik.

Sedangkan kemampuan literasi digital mahasiswa dalam mendesain evaluasi online berbasis google form mayoritas berada kategori advanced sebanyak 7 group teacher dari total yang diteliti 10 group teacher atau sebanyak 70\%, 2 group teacher berada pada kategori medium atau sebanyak 20\% dan 1 group teacher berada pada kategori basic atau sebanyak 10\%. Hal ini menunjukkan bahwa 70\% mahasiswa mempunyai kemampuan dalam mengoperasikan dan mengakses media pembelajaran sangat tinggi, memiliki pengetahuan yang tinggi sehingga mampu menganalisa konten media secara mendalam, dan mampu berkomunikasi secara aktif melalui media pembelajaran yang sudah disediakan sehingga mampu mendesain evaluasi online berbasis google form dengan sangat baik.

Berdasarkan hasil tersebut dapat disimpulkan bahwa implementasi blended learning pada mata kuliah SKI MI sebagai penguatan literasi digital mahasiswa jurusan Pendidikan Guru Madrasah Ibtidaiyah Sekolah Tinggi Ilmu Al-Qur'an berjalan dengan sangat baik.

\section{KESIMPULAN}

Implementasi blended learning diterapkan dengan menggunakan Alternative Model Blended Learning terdiri tiga tahapan yaitu 1) membuat rumusan capaian pembelajaran, dengan rumusan mahasiswa mampu mendesain pembelajaran online berbasis blogger dan evaluasi berbasis google form. 2) mendeskripsikan dan menyusun materi pembelajaran, yaitu materi tentang desain pembelajran dan evaluasi online berbasis google form. 3) menetapkan dan

Al-Madrasah: Jurnal Ilmiah Pendidikan Madrasah Ibtidaiyah

Vol. 6, No. 1, Januari-Maret 2022 
Muhammad Nasir, Syarifuddin, Ahmad Rifa'I : Implementasi Blended Learning Pada Pembelajaran SKI MI Sebagai Penguatan Literasi Digital Mendesain E-Learning Berbasis Blogger dan Google Form

menentukan aktivitas pembelajaran, aktifitas npembelajaran dilaksanakan 3 kali pertemuan 2 pertemuan online dengan menyediakan video pembelajaran yang diupload ke platform youtube dan 1 pertemuan offline untuk proses simulasi dan laporan desain e-learning berbasis blogger dan google form.

Kemampuan literasi digital mahasiswa dalam mendesain pembelajaran berbasis blogger mayoritas berada kategori advanced sebanyak 6 group teacher dari total yang diteliti 10 group teacher atau sebanyak 60\% mahasiswa mempunyai kemampuan dalam mengoperasikan dan mengakses media pembelajaran sangat tinggi, memiliki pengetahuan yang tinggi sehingga mampu menganalisa konten media secara mendalam, dan mampu berkomunikasi secara aktif melalui media pembelajaran yang sudah disediakan sehingga mampu mendesain e-learning berbasis blogger dengan sangat baik.

Sedangkan kemampuan literasi digital mahasiswa dalam mendesain evaluasi berbasis google form mayoritas berada kategori advanced sebanyak 7 group teacher dari total yang diteliti 10 group teacher atau sebanyak 70\% mahasiswa mempunyai kemampuan dalam mengoperasikan dan mengakses media pembelajaran sangat tinggi, memiliki pengetahuan yang tinggi sehingga mampu menganalisa konten media secara mendalam, dan mampu berkomunikasi secara aktif melalui media pembelajaran yang sudah disediakan sehingga mampu mendesain evaluasi online berbasis google form dengan sangat baik.

\section{DAFTAR PUSTAKA}

Anggrasari, Liya Atika. "Penerapan E-Learning Untuk Meningkatkan Kemampuan Literasi Digital Di Era New Normal." Premiere Educandum: Jurnal Pendidikan Dasar Dan Pembelajaran 10, no. 2 (December 1, 2020): 248-56. https://doi.org/10.25273/pe.v10i2.7493.

Arief, Rachman. "Aplikasi Presensi Siswa Online Menggunakan Google Forms, Sheet, Sites, Awesome Table Dan Gmail” 2017 (2017): 8.

Fathurrahman. Membuat Website Mudah dan Praktis dengan Weebly. Jakarta: Elex Media Komputindo, 2014.

Firman, Firman, and Sari Rahayu. "Pembelajaran Online Di Tengah Pandemi Covid-19." Indonesian Journal of Educational Science (IJES) 2, no. 2 (April 27, 2020): 81-89. https://doi.org/10.31605/ijes.v2i2.659.

Habibi, Ibnu. "Implementasi Pembelajaran Pendidikan Agama Islam Berbasis Daring (Whatsapp Group, Google Classroom Dan Zoom Meeting) Di SMP MBS Al Amin Bojonegoro." CENDEKIA 12, no. 2 (October 23, 2020): 161-78. https://doi.org/10.37850/cendekia.v12i2.134.

Al-Madrasah: Jurnal Ilmiah Pendidikan Madrasah Ibtidaiyah

Vol. 6, No. 1, Januari-Maret 2022 
Muhammad Nasir, Syarifuddin, Ahmad Rifa'I : Implementasi Blended Learning Pada Pembelajaran SKI MI Sebagai Penguatan Literasi Digital Mendesain E-Learning Berbasis Blogger dan Google Form

Hadi Sutopo, Ariesto. Teknologi Informasi Dan Komunikasi Dalam Pendidikan. Yogyakarta: Graha Ilmu, 2012.

Kenali 4 Kekurangan Sistem Pendidikan Online Berbasis Open-Source. "Kenali 4 Kekurangan Sistem Pendidikan Online Berbasis Open-Source." Accessed January 22, 2022. https://www.akubelajar.id/blog/kenali-4-kekurangan-sistem-pendidikan-online-berbasisopen-source.

"Kesulitan Akses Internet, Siswa Di Nagekeo Berjuang Cari Sinyal Hingga Ke Perbukitan Regional Liputan6.Com.” Accessed January 22, 2022. https://www.liputan6.com/regional/read/4503480/kesulitan-akses-internet-siswa-dinagekeo-berjuang-cari-sinyal-hingga-ke-perbukitan.

Nopitasari, Erna, Fitri Puji Rahmawati, and Wahyu Ratnawati. "Blended Learning Berbasis Blog Sebagai Inovasi Pembelajaran Pada Masa Pandemi Untuk Meningkatkan Motivasi Belajar Peserta Didik Kelas 3 Sekolah Dasar." Educatif Journal of Education Research 4, no. 1 (2022): 1-7. https://doi.org/10.36653/educatif.v4i1.86.

Nursobah, Ahmad. "Pemanfaatan Media Sosial Youtube Pada Pembelajaran Sejarah Kebudayaan Islam Di Madrasah Ibtidaiyah." El Midad 13, no. 2 (December 22, 2021): 76-85. https://doi.org/10.20414/elmidad.v13i2.4122.

Putri, Rahmawida. Model Blended Learning Berbasis Quided Inquiry. Sukoharjo: Penerbit Tahta Media Group, 2021.

Sugiyono. Cara mudah menyusun skripsi, tesis, dan disertasi (STD). Bandung: Alfabeta, 2013.

Trilaksono, Agustinus Rio, T. Husain, and Rouly Doharma. "Uji Model Keberhasilan Sistem Informasi: Media Penyimpanan Google Drive." Jurnal Teknologi Sistem Informasi dan Aplikasi 3, no. 2 (April 30, 2020): 57-63.

Ujulawa, Matilda. "Perancangan Learning Management System (LMS) Menggunakan Moodle Pada Sekolah Tinggi Tarakanita Jakarta." Komputasi: Jurnal Ilmiah Komputer \& Sistem Informasi 16, no. 1 (2017): 61-69.

Wati, Dwi Suseno, Sardianto Markos Siahaan, and Ketang Wiyono. "Efektivitas Learning Management System Chamilo Materi Gerak Harmonik Sederhana Terhadap Hasil Belajar Peserta Didik." LENSA (Lentera Sains): Jurnal Pendidikan IPA 11, no. 2 (October 31, 2021): 100-109. https://doi.org/10.24929/lensa.v11i2.166.

Wiriadinata, Windo, and Fahmil Haris. "Tingkat Pemahaman Guru Penjas Terhadap Penerapan ELearning Dalam Proses Pembelajaran Di Sekolah Menengah Pertama Kabupaten Limapuluh Kota Bukik Barisan.” Jurnal Stamina 2, no. 12 (2019): 12-19.

Zaharah, Zaharah, Galia Ildusovna Kirilova, and Anissa Windarti. "Impact of Corona Virus Outbreak Towards Teaching and Learning Activities in Indonesia." Salam: Jurnal Sosial Dan Budaya Syar-i 7, no. 3 (2020): 269-82.

Al-Madrasah: Jurnal Ilmiah Pendidikan Madrasah Ibtidaiyah

Vol. 6, No. 1, Januari-Maret 2022 